\title{
THE COMMUNICATIVE ABILITIES OF MILD MENTAL RETARDATES
}

\author{
RUTH BLUESTONE B.A. (SP. \& H. THERAPY) (WITWATERSRAND) \\ Department of Speech Therapy, Johannesburg Hospital, Johannesburg.
}

\section{SUMMARY}

The interpersonal communicative abilities of five mild mental retardates are investigated and described. One test of interpersonal communication was chosen from the literature. In the test situation, the experimenter taught each subject/speaker how to play a simple board game. Each speaker then taught the game to a listener of similar mental age. The channels of communication, both verbal and nonverbal, used by the speakers to explain the game items, were determined. The speakers' speech style (productivity, vocabulary and utterance structure) was evaluated qualitatively. Results indicated that all the speakers used both verbal and nonverbal communication behaviours to explain the rules of the gamc. Unlike the experimenter, the speakers utilized nonverbal behaviours (pointing and manipulation of the game material) as a distinct mode of communication. The speakers used an egocentric speech style and they all, unlike the experimenter, used speech to help the listener play the game correctly. The communicative ability of the speakers was not found to be commensurate with their mental ages and it was postulated that their inferior cognitive abilites predisposed them to use both primitive nonverbal behaviours and an egocentric speech style.

\section{OPSOMMING}

Die onderlinge kommunikasie vermoë van vyf matig verstandelikvertraagde persone is getoets en beskryf. Een toets van onderlinge kommunikasie is gekies uit die literatuur. In die toetssituasic het die proefnemer elke proefpersoon/spreker geleer hoe om 'n eenvoudige bordspeletjie te specl. Elke spreker het toe die speletjie aan 'n luisteraar van soortgelyke verstandelike ouderdom geleer. Die bane van kommunikasie, sowel verbaal as nie-verbaal wat ter verduideliking van die spelitems deur die sprekers gebruik is, is vasgestel. Die sprekers se spraakwyse (produktiwiteit, woordeskat en uitdrukkingstruktuur) is kwalitatief geëvalueer. Uit resultate wil dit voorkom dat alle sprekers sowel verbale as nie-verbale kommunikasiegedrag gebruik het on die spelreëls te verduidelik. Anders as die proefnemer, het dic sprekers as 'n duidelike kommunikasicmetode gebruik gemaak van-nie-verbale gedrag (wys met die vinger en manipulasie van die spelmateriaal). Die sprekers het gebruik gemaak van 'n egosentriese spraakwysc en het almal, anders as die proefnemer, van taal gebruik gemaak om die luisteraar te help om dic spcletjie korrek te speel. Die kommunikasievermoë van die sprekers was nie eweredig aan hulle verstandelike ouderdom nie en is dit gepostuleer dat hulle laer kogniticwe vermoë tot die gebruik van sowel primitiewe nie-verbale gedrag en egosentriese spraakwyse aanleiding gee.

The Speech Therapist, in dealing with the problems of communication, must of necessity deal with the problem of mental retardation and the associated communication problems arising from this condition. Lillywhite and Bradley ${ }^{14}$ state that of all the types of human problems resulting in major communication disorders, mental retardation is perhaps the least understood, the most puzzling and the most neglected by Speech and Hearing Specialists.

A great many studies have demonstrated that language deficiencies in the form of speech defects occur in retarded children. $7,12,21,24,26$ 
The reported incidence figures vary considerably, but one fact that can be gleaned from the literature is that mental retardation and linguistic retardation are correlates.

Individuals are classified as being mentally retarded when their Intelligence Quotients (IQ) fall below a certain limit. The American Association on Mental Deficiency designates five different categories of retardation. ${ }^{4}$ The present study was concerned with those subjects classified as mild or educable mental retardates, that is, those having an IQ between 50 and $75 .{ }^{23}$

The reported incidence figures of the speech and language problems amongst this subgroup of mental retardates, varies considerably. Most researchers ${ }^{23,24,26}$ however do indicate that the mildly retarded child presents with many more speech and language problems than would be found in the normal population.

According to the above writers, ${ }^{24,24,26}$ the mild or educable retardate is very rarely unable to communicate at all and does acquire some usable language. The child therefore can be said to acquire a phonology, a morphology and a syntax, although these aspects may not be adequate for his age.

An important consideration is how the child uses his acquired language to communicate ${ }^{22}$, for as well as learning the syntax and vocabulary of language, the child must learn to use them appropriately in different situations and with different communicative partners. The field of pragmatics is therefore concerned with how language is used to communicate and emphasis is given on how a person uses his language, apart from the structure or content of the language system itself. ${ }^{9}$

The language of an individual may therefore be assessed in two ways, namely, intrapersonally and interpersonally. In the former method, one investigates how language develops within the individual ${ }^{15}$ by assessing aspects such as the child's vocabulary, sentence structure and articulation. In the field of mental retardation, comparisons are then made between the mental retardate's intrapersonal language and the language of the normal child, of similar mental or chronological age.

In interpersonal assessment, however, the focus is on the flow of behaviour between a speaker and a listener. This method, according to Siegel $^{25}$ seems to be especially cogent in the study of communication disorders since speech events are almost always interpersonal, involving both a listener and a speaker.

The present study was concerned with the question of how mildly retarded speakers utilize their existing language to communicate and for this reason the latter method of investigation was chosen.

In everyday communicative situations, the involved and complex patterns of exchange between speaker and listener are not easy to study and evaluate. Interpersonal communication tasks in which the communication episode can be readily observed and objectively described have however been developed by a number of 
researchers. $1,2,5,10,13,15,16$ There are no formal tests in this area and therefore the experimenter is reliant on his/her ability to adapt the material and tests used in the literature to meet the needs of the subjects under study.

\section{METHODOLOGY}

AIM

To describe the interpersonal communicative abilities of mild or educable mental retardates.

\section{SUBJECTS}

Ten subjects, five speakers and five listeners, were used. The speakers constituted the primary subjects of this study and it was their communication that was studied. None of the speakers participated as listeners and vice versa.

A control group of normal subjects was not used as this study was not concerned with comparing the communicative abilities of normal and mentally retarded speakers. From the literature it can be seen that mental retardation and linguistic retardation are correlates, ${ }^{7}, 12,21,24$, 26 and that the mild mental retardate presents with many more speech and language problems than would be found in the normal population. ${ }^{23,24,26}$

\section{Criteria for speaker selection}

1. Intelligence: All speakers were required to be classified as mild or educable retardates, that is, to have an IQ between 50 and $75 .^{23}$

2. Mental Age: All speakers were required to have a mental age (MA) above 8 years. This particular MA was chosen for the following reasons: MA seems to be a more accurate predictor of speech and language abilities than chronological age. ${ }^{8,} 14$ In addition, only after eight years of age is the normal child able to use his language most effectively for the purpose of communication. ${ }^{17}$

3. Hearing: To eliminate inadequate peripheral functioning as further possible etiology of linguistic impairment, speakers were required to have normal hearing.

4. Schooling: All speakers were required to have spent a minimum of two years in a normal school ênvironment and a minimum of four years in a special education class in a Private or Government School. At the time of the study they were all required to be attending the same Private School and to have been exposed to the same teacher for a minimum of two years. Speakers who had just joined the class or who had recently begun attending the school, were not included in the study.

5. Previous training or therapy: Apart from receiving special education in the school, none of the speakers had received any form of additional training in the form of speech therapy. 
6. Sex: Due to the lack of availability of speakers and the importance of selecting speakers according to MA and IQ, this factor could not be controlled for and all speakers were females.

7. Home language: All speakers were required to be English speaking and to have been exposed to a single home language.

8. Test factors: All speakers were.required to have been tested on the same IQ test (Wechsler Intelligence Scale for Children) by the same tester (School Psychologist) at approximately the same time (six months prior to the study) and under the same conditions (the school environment).

\section{Criterion for listener selection}

Five listeners were selected and each speaker was paired with a listener of similar MA. The rationale for matching dyads according to MA is as follows: Research has shown that both adults and children alter their encoding strategies as a function of the age and ability of the listener with whom they are paired. ${ }^{19}$ Rosenberg et $\mathrm{al}^{18}$ and Hoy and $\mathrm{McKnight}^{10}$ found that retarded children communicate more and more effectively when placed with listeners of similar linguistic ability than when placed with listeners of superior linguistic ability. If MA is an accurate predictor of linguistic ability ${ }^{8,14}$ then pairing dyads according to MA ensures homogeneity and according to the literature cited above $\mathrm{e}^{10,18}$ homogeneity facilitates verbal interaction.

\section{PILOT STUDY}

There are no formal tests of interpersonal communication and although a number of test paradigms have been set up by a number of different researchers, 1, 2, 5, 10, 13, 15, 16 each test assesses a different aspect of communication and in addition some tests are more effective than others.

As a result, a detailed pilot study (which cannot be elaborated on in the present article) was carried out. The primary aims of this pilot study were: to select appropriate tests of interpersonal communication that have been used in the literature; to administer and thereafter evaluate the efficacy of these tests; and on the basis of the above findings to select the most effective test in terms of the present study and the population being assessed.

DESCRIPTION OF CHOSEN TEST

On the basis of the results of the above pilot study, one test of interpersonal communication, developed by Hoy \& McKnight; ${ }^{10}$ was chosen as the most effective test for the purpose of this study. Certain modifications were however introduced.

Basically, in this test situation, the speaker is required to explain the rules of a simple board game to a listener.

The test consists of the following equipment: 
1. A game board: A 46 centimetre square with six $(7,6$ centimetre wide) stripes, alternately blue and yellow, running horizontally across the board and a black line running vertically down the centre of the board, delineating each player's side.

2. Two movers: one red and one green car.

3. A dice: a four centimetre cube with three blue and three yellow surfaces.

From the pilot study, it was determined that in order to teach the listener how to play the game, the speaker must convey ten items of game information. In addition, different channels of communication can be used to explain each item. The three main channels are the verbal $(V)$, gestural $(G)$ and manipulative $(M)$ where gesture is defined as a hand movement in the air and manipulation as actual touching and moving of the game material. ${ }^{10}$

During the pilot study it was observed however, that it is difficult to separate out a gestural response from a manipulative one and therefore these two channels were combined into one nonverbal channel. During the study therefore, only three channels of communication were used:

1. Verbal Channel (V) where speech alone is used to explain a game item.

2. Verbal-Gestural-Manipulative Channel (V-G/M) where speech is used together with gesture and/or manipulation.

3. Gestural-Manipulative Channel (G/M) where gesture and/or manipulation is used without speech.

\section{TESTING}

Testing involved the following four steps:

1. The experimenter taught the speaker how to play the game.

The speakers were each instructed individually and as far as possible the experimenter's instructions to each speaker were standardized. One channel of communication (V-G/M) was selected and the same speech and nonverbal behaviour was used to explain each game item.

2. The experimenter and speaker played the game twice.

This was done to ensure that each speaker had understood the rules of the game. Speakers were said to have understood the rules if they were able to play the game correctly twice in a row, without any prompting. They were said not to have understood the game if they hesitated before moving, made an incorrect move or asked questions about the game.

An independent rater was used to help the experimenter note the above responses and in addition a tape recording was made of each speaker's verbal behaviour.

3. The speaker taught the game to a listener.

Each speaker's verbal explanation of the game was tape recorded for later analysis. In addition, the nonverbal aspects of the 
description were rated by both the experimenter and an independent rater.

The experimenter and rater each had a score sheet with the items to be communicated listed vertically and the channels of communication listed horizontally. The experimenter and rater sat on either side of the dyad and thus were unable to observe each other's score sheets.

4. The speaker and listener played the game twice.

Once the speaker had finished explaining the game to the listener, they too played the game twice. So that this could be later analyzed, a tape recording of their verbal interaction was made.

TRANSCRIPTION OF THE DATA

The speech of the speakers, both while explaining the game and during both playings of the game, was transcribed. Any comments made by the listeners, were also transcribed. If during the playing of the game with the experimenter, the subjects or the experimenter used speech, this was also transcribed.

ANALYSIS OF THE DATA

The data analysis procedures, suggested by Hoy \& McKnight, ${ }^{10}$ were used. The following areas were considered but will not all be discussed in the present article:

1. The number of game items communicated by each speaker.

2. The channels of communication used by each speaker.

3. Speech Style.

(a) Productivity

(i) Total number of words

(ii) Total number of utterances

(b) Vocabulary

(i) Number of different words used

(ii) Type Token Ratio as defined by Carroll. ${ }^{3}$

(b) Utterance Structure

(i) Number of imperatives

(ii) Number of declaratives

(iii) Number of questions

The above procedures were used:

1. To analyse the speech used by the experimenter to explain the rules to each speaker.

2. To analyse the speech used by each speaker to explain the game to a listener.

3. To analyse the speech used by each speaker whilst playing the game with the listener.

\section{RESULTS AND DISCUSSION}

1. NUMBER OF GAME ITEMS EXPLAINED BY EACH SPEAKER (s).

The mean number of items communicated by the group is equal to 8,8 .

Die Suid-Afrikaanse Tydskrif vir Kommunikasieafwykings, Vol. 27, 1980 
From Table $I$ it can be seen that five Ss omitted one game item and that only one out of the five Ss omitted two items.

TABLE I: Total number of game items explained by each speaker regardless of channels used. (Total is equal to 10)

\begin{tabular}{|c|c|c|c|c|}
\hline S1 & S2 & S3 & S4 & S5 \\
\hline 8 & 9 & 9 & 9 & 9 \\
\hline
\end{tabular}

2. THE CHANNELS OF COMMUNICATION USED BY EACH S.

From the above table (Table I) it can be seen that a total of forty four game items were explained by the group. Of these, two were explained through the $V$ channel, eighteen through the $V-G / M$ and twenty four through the G/M channel.

The output of the group must be evaluated in terms of the input they received. Although Ss were not told how to go about the task, they did have a model, the experimenter's (E) description, upon which to base their explanations. The question to be asked is whether there is any correlation between the way the Ss explained the game items and the way the $E$ explained them in terms of the channels of communication used.

From Table II it can be seen that the E used one channel, the V-G/M, to explain each item. The $E$ therefore used this channel $100 \%$ of the time. On average, the Ss used this channel only $41 \%$ of the time. As a

TABLE II: The percentage of game items explained through each of the three channels, including a comparison between channels used by the experimenter (E) and speakers (Ss) to explain the game.

\begin{tabular}{|c|c|c|c|}
\hline & V & V-G/M & $\mathrm{G} / \mathrm{M}$ \\
\hline E & - & 100 & - \\
\hline $\begin{array}{c}z==\leq a== \\
\text { S1 }\end{array}$ & $==-$ & $\begin{array}{c}== \pm=2=8 z \\
12\end{array}$ & $\begin{array}{c}z==2=28 \\
88\end{array}$ \\
\hline S2 & - & 44 & 56 \\
\hline S3 & 11 & 44 & 44 \\
\hline S4 & 11 & 56 & 33 \\
\hline S5 & - & 44 & 56 \\
\hline MEAN & 4 & 41 & 55 \\
\hline
\end{tabular}

The South African Journal of Communication Disorders, Vol. 27, 1980 
group, they used the G/M channel more frequently, that is, $55 \%$ of the time.

The results depicted in Table II therefore indicate that all the Ss in this study relied to some extent, some more than others, on a nonverbal channel of communication (the G/M channel) to explain the rules of a game to a listener. The above results correspond with those obtained by Hoy \& Mcknight. ${ }^{10}$

\section{SPEECH STYLE USED TO EXPLAIN THE RULES OF THE GAME.}

(a) Productivity

The results depicted in Table III indicate that as a group the Ss used fewer words and utterances than the $E$. If the Ss used a nonverbal channel more frequently than the $E$ to explain the game items (see Table II) then it can be expected that they will use less speech than the $E$ to explain the items.

This large discrepancy between the E's and Ss' productivity, indicates, therefore, that the verbal channel does not constitute a primary mode of communication for the $S$ in this study. The $E$, on the other hand, utilised the verbal channel as a primary mode of communication and gesture and/or manipulation was used by the $\mathrm{E}$ only to supplement verbal instructions. The Ss, unlike the $E$, used gesture and/or manipulation as a separate, substitutive channel of communication.

TABLE III: A comparison between the productivity of the E and Ss.

\begin{tabular}{|c|c|c|}
\hline $\mathrm{E}$ & $\begin{array}{c}\text { Number of } \\
\text { words }\end{array}$ & $\begin{array}{c}\text { Number of } \\
\text { utterances }\end{array}$ \\
\cline { 1 - 1 } MEAN Ss & 149 & 17 \\
\hline
\end{tabular}

(b) Utterance Structure

In terms of utterance structure, there are similarities between the way the $E$ explained the game items and the way the Ss explained them in that they both utilised a predominantly declarative speech style.

A declarative speech style seems to be the most appropriate style to use to inform a listener about the rules of a game. Thus, even though the Ss in this study, did not utilise verbal communication as their primary mode, the speech they did use was utilised in the most effective way possible in terms of informing the listener about the rules of a game. 
4. SPEech STYLE USED WhILST PLAying THE GAME WITH A ListeneR.

In this section, a comparison cannot be made between the E's and Ss' speech style, as the E did not use speech whilst playing the game with any of the Ss. Thus once the rules had been explained, the $S$ s understood them and did not need an additional explanation.

Unlike the E, the Ss all used speech whilst playing the game with a listener. Speech was used only during the first playing of the game.

TABLE IV: A comparison between the number of words used during the explanation and during the first game.

\begin{tabular}{|l|c|c|c|c|c|}
\hline & \multicolumn{5}{|c|}{ NUMBER OF WORDS USED } \\
\hline SPEAKERS & S1 & S3 & S5 & S2 & S4 \\
\hline PLAYING & 44 & 35 & 34 & 30 & 24 \\
\hline EXPLAINING & 18 & 51 & 61 & 68 & 67 \\
\hline
\end{tabular}

Table IV indicates that there is an inverse relationship between the number of words used to explain the game and the number of words used whilst playing the game: Ss who used the least amount of speech to explain the game used the most speech whilst playing the game. Thus, as the number of words used whilst playing the game decreased, so the number of words used whilst explaining the game increased.

As a group the Ss all used a nonverbal channel of communication to explain the rules of the game. Unlike the $\mathrm{E}$, they all used speech whilst playing the game with a listener. There seems therefore, to be a relationship between the use of nonverbal communication to explain the rules and subsequent use of speech whilst playing the game.

\section{GENERAL DISCUSSION}

It is generally accepted that a speaker can encode a message through a number of different channels: ${ }^{20}$ (1) the speech mechanism; (2) the hands and arms; (3) the face and (4) other body parts. Verbal language is therefore only one method of human communication.

The results of this study indicate that all the speakers encoded information both verbally (by means of speech) and nonverbally (by means of gesture and/or manipulation). The speakers used nonverbal communication both to supplement and as a substitute for verbal communication. It may therefore be postulated that nonverbal communication constituted an important mode of communication for the mentally retarded subjects in this istudy.

In order to evaluate the above, it is important to consider the type of nonverbal communication used by the speakers. Only hand and arm gestures were used and more specifically, the speakers used either pointing or manipulation of the game material to explain the items. 
Although it has been determined that the speakers used nonverbal behaviours as a distinct mode of communication, the exact nature of nonverbal communication and its relationship to verbal communication is not clear. Two different views have been postulated.

One point of view is that nonverbal communication includes any code items that are not part of language. ${ }^{9}$ These behaviours (nonverbal) according to Jancovic et $\mathrm{al}^{11}$ are nothing but primitive substitutes for more complex verbal forms and are therefore more trivial in comparison to verbal communication behaviours. ${ }^{11}$

The alternative view states that although language may receive a visual-gestural encoding, it still must be considered as language. In addition the nonverbal channel has the possibility of being elaborated to the same extent to which the verbal channel is known to be elaborated. $^{11}$

The writer believes that although we can view communication as a matrix of both verbal and nonverbal channels, and although there is the possibility of interdependence between channels, speech must be seen as the most sophisticated form of adaptive behaviour. ${ }^{20}$ In addition, some forms of nonverbal behaviour must be viewed as primitive precursors to later verbal forms. The writer believes that because pointing is evident in the prelinguistic child ${ }^{9}, 11,20$ and because this type of nonverbal behaviour disappears from the child's repertoire when more complex verbal forms appear, ${ }^{11}$ pointing must be viewed as a primitive and unsophisticated form of nonverbal behaviour.

With regard to the results obtained in the present study, the following two questions need to be answered:

1. Why did the mental retardates in this study rely to such a great extent on nonverbal communication?

Every communication system places demands upon cognitive function, but the extent of the demand varies with the sophistication of the system. ${ }^{20}$ Verbal language requires a sophisticated use of linguistic rules, in addition to cognitive function. Nonverbal communication, on the other hand, places less of a demand upon cognitive function.

The important relationship that exists between cognition and language cannot be ignored. If, as stated above, the form of communication used, depends on cognitive ability, then analysis of the communication channels used by the speakers, can give insight into their cognitive development.

Zigler, as cited by Weisz, ${ }^{27}$ holds the view that persons of differing $I Q$ but similar $M A$ will manifest cognitive differences inherently related to $I Q$. Thus retarded persons will be cognitively inferior to non-retarded persons of similar MA.

If the mental retardates in this study are functioning inferiorly on a cognitive level, then this can account for their frequent use of a primitive nonverbal communication system. A corollary to this view is that the mental retardates frequent use of the nonverbal 
channel indicates that they are functioning inferiorly on a cognitive level.

2. Was the communication used by the speakers effective in producing listener understanding?

The effectiveness of communication and listener understanding were not evaluated in an objective manner. The results of the study do seem to indicate, however, that the explanations given by the speakers were not in fact effective in producing understanding of the game. All the speakers understood the rules of the game, yet they all, unlike the experimenter, used speech whilst playing the game with the listener. This seems to indicate that, had the speakers not used speech, the listeners would not have been able to play the game correctly.

It may be postulated that two interrelated factors affected communication, namely, the speakers' use of nonverbal communication channels, as well as their inadequate role-taking abilities.

In order to play the communication game effectively, the speaker must realize that effective communication can only occur if he (the speaker) makes appropriate consideration of the other participant/s in the communication process. ${ }^{17}$ This awareness of communication as a two-way process is known as role-taking. ${ }^{5}$

Role taking abilities are only fully developed after eight years of age and prior to age eight, communicative efforts are governed by limitations in cognitive development. ${ }^{17}$ Cognition, language usage and communication are inextricably related ${ }^{17}$ and it therefore may be postulated that the speakers in this study are delayed cognitively and that their cognitive limitations affected the nature of their communications.

If, as the results of this study suggest, communication was non-communicative, then the nature of non-communicative language must be discussed. Piaget, as cited by Ginsburg \& Opper ${ }^{6}$, uses the term egocentric speech to define the speech of the young child.

Results of this study seem to indicate that the speakers used egocentric communication. They internalized the rules of the game and as such they were meaningful and communicable to themselves. They then transmitted the rules without first recoding them. The rules were obscure to the listener and they were unable to play the game. In order to overcome this difficulty, and because the speakers were motivated to play' the game, they used speech to help the listener.

The use of egocentric speech indicates that underlying idiosyncratic cognitive systems are not fully developed. ${ }^{17}$ In addition, egocentric speech is characteristic of the speech of the young child, below eight years. If as indicated above, the speakers in this study used an egocentric speech style, then one can postulate that their under- 
lying cognitive systems are not fully developed and that in additiom, their communicative behaviour is not commensurate with their mental ages.

\section{CONCLUSION}

The results obtained in this study indicate that in interpersonal communication situations, mildly retarded speakers utilize and rely to a great extent on nonverbal communication channels. The verbal channel does not therefore constitute the primary communication mode for these speakers. In terms of speech therapy for the retarded, therefore, the following needs to be considered. Should speech therapy aim to make the mildly retarded child predominantly verbal or should attempts be made to increase, not exclude the child's use of nonverbal communication behaviours?

In order to plan appropriate therapy for the mentally retarded child, factors such as his language needs, age and degree of retardation must be considered.

The older, school-going, mildly retarded individual should potentially be able to acquire the specific skills necessary for certain jobs. Speech therapy or classroom training should therefore be aimed at helping this child become integrated into a predominantly verbal society. The child should be helped to acquire the skills, both verbal and otherwise, that are necessary for specific jobs. Although the mild retardate's use of nonverbal communication should not be ignored, attempts should be made to make this child's verbal communication skills at least commensurate with his mental age.

Speech therapy for the low grade retardate (the moderately or severely retarded) cannot however always be aimed at teaching the child a fully developed adult system of communication. The goal of therapy with this retardate should be to provide the child with a system of communication that is both effective and functional. The writer feels that for the low grade retardate, facilitation of nonverbal communication, should constitute the primary focus of therapy. It may be that the use of nonverbal communication is a means by which retarded children, who are too low on a cognitive level to learn to speak adequately, can learn to communicate.

\section{REFERENCES}

1. Beveridge, M. C. (1976): Patterns of interaction in the mentally handicapped. In Language and Communication in the Mentally Handicapped, Berry, P. (Ed.) Edward Arnold.

2. Beveridge, M. C., \& Tatham, A. (1976): Communication in retarded adolescents: Utilization of known language skills. American Jnl. of Mental Deficiency, 81(1), 96-99.

3. Carroll, J. B. (1964): Language and Thought. Foundations of modern psychology series, Prentice-Hall, Inc. N. J. 
4. Davison, G. C., \& Neale, J. M. (1974): Abnormal Psychology: An Experimental-Clinical Approach. John Wiley \& Sons. N. Y.

5. Flavell, J. J., Botkin, P. T., Fry, C. L., Wright, J. W., \& Jarvis, P. E. (1968): The Development of Role Taking and Communication Skills in Children. John Wiley \& Sons. N. Y.

6. Ginsburg, H., \& Opper, S. (1969): Piaget's Theory of Intellectual Development: An Introduction. Prentice-Hall, Inc. N. J.

7. Goertzen, S. M. (1957): Speech and the mentally retarded child. American Jnl. of Mental Deficiency, 62(2), 244-253.

8. Graham, J. T., \& Graham, L. W. (1971): Language behaviour of the mentally retarded: Syntactic characteristics. American Jnl. of Mental Deficiency, 75(5), 623-629.

9. Hopper, R., \& Naremore, R. (1978): Children's Speech: A Practical Introduction to Communication Development. Harper \& Rowe.

10. Hoy, E. A., \& McKnight, J. R. (1977): Communication style and effectiveness in homogeneous and heterogeneous dyads of retarded children. American Jnl. of Mental Deficiency, 81(6), 587-598.

11. Jancovic, M., Devoe, S., \& Wiener, M. (1975): Age related changes in hand and arm movements as nonverbal communication: Some conceptualizations and an empirical exploration. Child Development, 46(4), 922-928.

12. Karlin, I. W., \& Strazzulla, M. (1952): Speech and language problems of mentally deficient children. J. Speech Hear. Dis., 17, 286-294.

13. Krauss, R. M., \& Glucksberg, S. (1969): The development of communication: Competence as a function of age. Child Development, 40(1), 254-265.

14. Lillywhite, H. S., \& Bradley, D. P. (1969): Communication Problems in Retardation: Diagnosis and Management. Harper \& Rowe.

15. Longhurst, T. (1972): Assessing and inreasing descriptive communication skills in retarded children. Mental Retardation, 10(2), $42-45$.

16. Longhurst, T., \& Reichle, J. (1975): The applied communication game. J. Speech Hear. Dis., 40(3), 315-319.

17. Muma, J. R. (1975): The communication game: Dump and play. J. Speech Hear. Dis., 40(3), 296-307.

18. Rosenberg, S., Spradlin, J., \& Mabel, S. (1961): Ińteraction among retarded children as a function of relative language skills. Jnl. of Abnormal and Social Psychology, 63(2), 402-410.

19. Sachs, J., \& Devin, J. (1976): Young children's use of age appropriate speech styles in social interaction and role playing. Jnl. of Child Language, 3, 81-98!

20. Sanders, D. A. (1976): A model for communication. In Communication Assessment and Intervention Strategies, Lloyd, L. (Ed.) University Park Press. 
21. Saunders, E. A., \& Miller, C. J. (1968): A study of verbal communication in mentally subnormal patients. Brit. Jnl. of Dis. of Comm., 3(1), 99-110.

22. Schiefelbusch, R. L. (1967): Introduction. In Language and Mental Retardation, Schiefelbusch, R., Copeland, R. \& Smith, J. (Eds.) Holt Rinehart \& Winston, Inc.

23. Schlanger, B. S. (1973): Mental Retardation. Bobbs-Merrill Studies in Communicative Disorders.

24. Sheehan, J., Martyn, M., \& Kilburn, K. (1968): Speech disorders in retardation. American Jnl. of Mental Deficiency, 73(2), 251256.

25. Siegel, G. M. (1967): Interpersonal approaches to the study of communication disorders. J. Speech Hear. Dis., 32, 112-120.

26. Spreen, O. (1965): Language functions in mental retardation: A review I. American Jnl. of Mental Deficiency, 69(4), 483-493.

27. Weisz, J. R. (1976): Studying cognitive development in retarded and nonretarded groups: The role of theory. American Jnl. of Mental Deficiency, 81(3), 235-239. 


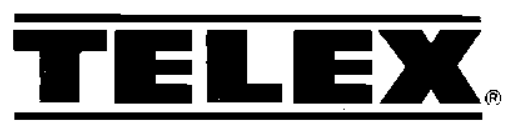

TELEX COMMUNICATIONS, INC.

\title{
DIRECT WIRELESS FM AUDITORY TRAINING SYSTEM
}

Look at these Features!!!

Transmitter: *Special cardioid directional michrophone for improved signal/noise ratio. "Auxiliary input for Radio, TV or Tape with "Talk-over" switch.

Receiver: "Two versions available- Normal and High Frequency Emphasis. * Tone, Compression and FM/MIC balance controls provided. * Selection of Earphones available. * Three operating modes- FM alone, + Hearing Aid and Hearing Aid Alone. " Channel selection by plug in Module- allows freedom of movement from one class to another without changing the receiver.

General: *32 different channells !!! * Dry cell or rechargeable energy source.

"Robust construction with michrophone protection cover.

\section{Hearing is Bliss}

203 Lancet Hall, 207 Jeppe Str., Johannesburg. 2001

SYD BLISS HEARING AIDS

(Pty) Ltd. Tel. 29-1239

\section{BOOKS ON SPEECH THERAPY AND AUDIOLOGY ARE STOCKED AT THESE BOOKSHOPS}

\author{
Campus Bookshop \\ 34 Bertha Street \\ P.O. Box 31361 \\ BRAAMFONTEIN 2017 \\ Johannesburg \\ Tel: $39-1711$ \\ Logans University Bookshop \\ (Pty) Ltd \\ 229 Francois Road \\ DURBAN \\ Tel: 25-3221 \\ Pro Rege Bookshop \\ Tomstraat 86 \\ P.O. Box 343 \\ POTCHEFSTROOM 8875 \\ Tel: $8875 / 6$
}

\author{
Westdene Medio Boeke \\ 35-36 Nedbank Plaza \\ 175 Beatrix Street \\ PRETORIA \\ Tel: 26336 \& 33487 \\ Westdene Services \\ 76A King George Street, \\ Hospital Hill \\ HILLBROW \\ Johannesburg \\ Tel: 39-1711 \\ Campus Westdene Bookshopl \\ Boekhandel \\ Cnr. Grotto \& Main Roads \\ RONDEBOSCH \\ |Tel: $692-407$
}

\section{Literary Services (Pty) Ltd.}

